\title{
Daya Gabung dan Heterosis Galur Jagung (Zea mays L.) pada Karakter Hasil dan Komponen Hasil
}

\section{Combining Ability and Heterosis of Maize (Zea mavs L.) Inbreds for Yield and Yield Components}

\author{
Eko Purnomo Setyowidianto ${ }^{1^{*}}$, Nur Basuki ${ }^{2}$, dan Damanhuri ${ }^{2}$ \\ ${ }^{1}$ Program Magister Ilmu Tanaman, Pasca Sarjana, Fakultas Pertanian, Universitas Brawijaya Malang \\ ${ }^{2}$ Jurusan Budidaya Pertanian, Fakultas Pertanian, Universitas Brawijaya \\ Jl. Veteran, Malang 65145 Jawa Timur, Indonesia
}

Diterima 26 September 2016/Disetujui 4 Januari 2017

\begin{abstract}
Corn productivity can be improved using hybrid varieties. Evaluation of inbreds and hybrids were required to obtain information of general combining ability and specific combining ability. The objective of this research was to find out inbred combining ability and hybrids heterosis from crosses of 10 inbreds (5 inbreds from PT. Agri Makmur Pertiwi and 5 introduced inbreds) based on yield and yield components character. Diallel mating design using method 2 model 1 of Griffing model and the testing were conducted from January to August 2012. The tests using a randomized block design with three replications. PWM-1 (PT. Agri Makmur Pertiwi group) and PWI-5 (introduced group) have GCA better than other inbreds on grain yield, ear length, ear diameter, number of seed rows, shelling percentage and 1,000 seeds weight. Hybrids PWM-5 $x$ PWM-1, PWI$5 \times$ PWM-1 and PWI-5 $x$ PWM-5 have a positive SCA values and also inbred parent have a positive GCA value. Intercrosses of introduced group had the high heterosis for all characters. PWI-4 x PWI-2 had highest SCA and heterobeltiosis for ear diameter and 1,000 seeds weight, and for number of seed rows was PWI-5 $x$ PWI-2.
\end{abstract}

Keywords: diallel cross, heterobeltiosis

\section{ABSTRAK}

Produktivitas jagung dapat ditingkatkan menggunakan varietas hibrida. Evaluasi galur dan hibrida diperlukan untuk memperoleh informasi daya gabung umum dan daya gabung khususnya. Penelitian ini bertujuan untuk mengetahui daya gabung galur dan heterosis hibrida dari persilangan 10 galur (5 galur PT. Agri Makmur Pertiwi dan 5 galur introduksi) melalui karakter hasil dan komponen hasil. Persilangan dialel dengan model Griffing metode 2 model 1 dan pengujiannya dilakukan dari Januari-Agustus 2012. Pengujian menggunakan rancangan acak kelompok dengan tiga ulangan. Galur PWM-1 (grup PT. Agri Makmur Pertiwi) dan PWI-5 (grup introduksi) mempunyai DGU yang lebih baik dibandingkan dengan galur lain pada karakter hasil biji, panjang tongkol, diameter tongkol, jumlah baris biji, rendemen dan bobot 1,000 biji. Hibrida PWM-5 x PWM-1, PWI-5 x PWM-1 dan PWI-5 x PWM-5 mempunyai nilai DGK positif dan galur pembentuknya juga mempunyai nilai DGU positif. Hibrida pada grup introduksi mempunyai heterosis yang tinggi untuk semua karakter. Hibrida PWI-4 x PWI-2 mempunyai DGK dan heterobeltiosis tertinggi untuk karakter diameter tongkol dan bobot 1,000 biji, sedangkan untuk karakter jumlah baris biji yaitu hibrida PWI-5 x PWI-2.

Kata kunci: heterobeltiosis, persilangan dialel

\section{PENDAHULUAN}

Jagung merupakan salah satu tanaman sereal penting di dunia, termasuk Indonesia. Upaya untuk memenuhi kebutuhan jagung dan meningkatkan produktivitas jagung yaitu dengan menggunakan benih hibrida. Hibrida jagung dapat dihasilkan dari persilangan galur inbrida. Galur pada jagung dapat diperoleh melalui penyerbukan sendiri (selfing) atau melalui persilangan antar saudara (Takdir et al., 2007).

\footnotetext{
* Penulis untuk korespondensi. e-mail: ekopurnomos@yahoo.com
}

Pemilihan materi sebagai bahan dasar pembentukan galur harus memperhatikan latar belakang genetik. Seleksi secara bertahap yang dilakukan perlu memperhatikan daya gabung galur yang dihasilkan. Daya gabung galur pada awalnya merupakan konsep yang mempertimbangkan secara bersama untuk mengklasifikasikan galur dalam hubungan dengan performa persilangannya, yang dikemukakan oleh Sprague dan Tatum (1942). Daya gabung umum digunakan untuk merancang penampilan rerata dari suatu galur dalam kombinasi hibrida, sedangkan daya gabung khusus digunakan untuk merancang penampilan suatu galur dalam kombinasi tertentu apakah lebih baik atau lebih buruk dari 
yang diharapkan didasarkan pada penampilan rerata galur yang terlibat.

Persilangan dialel dapat digunakan untuk memilih tetua atau galur, serta analisisnya dapat digunakan untuk menentukan daya gabungnya. Persilangan yang dilakukan diantara semua pasangan tetua dapat mengetahui potensi hasil dari suatu kombinasi hibrida, nilai heterosis, daya gabung dan ragam genetik dari suatu karakter. Nilai daya gabung umum dan daya gabung khusus yang diperoleh dapat menentukan apakah galur-galur yang ada akan dibentuk menjadi varietas hibrida atau dibentuk menjadi varietas sintetik (Basuki, 2005).

Istilah heterosis sering disamakan dengan ketegapan hibrida, mengacu pada superioritas F1 yang dihasilkan terhadap tetuanya. Ekspresi heterosis hanya akan muncul pada generasi pertama saja, dan telah dimanfaatkan secara luas dalam pembentukan hibrida yaitu dari dua tetua (Poehlman dan Sleper, 1995). Heterosis pada jagung akan lebih besar pada persilangan dua tetua dengan hubungan kekerabatan jauh daripada persilangan dua tetua dengan hubungan kekerabatan dekat.

Tujuan penelitian ini adalah untuk mengetahui daya gabung umum, daya gabung khusus dan heterosis hibrida dari persilangan 10 galur (5 galur hasil pemuliaan PT. Agri Makmur Pertiwi dan 5 galur introduksi) melalui karakter hasil dan komponen hasil.

\section{BAHAN DAN METODE}

Penelitian ini dilaksanakan di Kebun Percobaan milik PT. Agri Makmur Pertiwi Kediri, untuk pembuatan materi percobaan, mulai Januari-Mei 2012. Tempat pengujian daya gabung dan heterosis dilaksanakan di Desa Jambu, Kecamatan Kayen Kidul, Kediri, pada bulan Mei-Agustus 2012. Bahan yang digunakan yaitu 5 galur PT. Agri Makmur Pertiwi (PWM-1, PWM-2, PWM-3, PWM-4 dan PWM-5) dan 5 galur introduksi dari Thailand (PWI-1, PWI-2, PWI3, PWI-4 dan PWI-5). Persilangan dialel dilakukan untuk menghasilkan materi genetik berupa 45 hibrida.

Penelitian dilaksanakan menggunakan Rancangan Acak Kelompok dengan tiga ulangan. Benih ditanam 2 baris dengan jarak $75 \mathrm{~cm}$ x $20 \mathrm{~cm}$, dengan luas plot $5.0 \mathrm{~m}$ x 1.5 $\mathrm{m}$. Perlakuan benih menggunakan fungisida berbahan aktif dimetomorf untuk mengendalikan penyakit bulai. Pupuk dasar menggunakan pupuk majemuk dengan dosis $300 \mathrm{~kg}$ NPK ha-1, pupuk tunggal $300 \mathrm{~kg}^{-1}$ urea ha ${ }^{-1}$ diberikan sebagai pupuk susulan I dan II. Pencegahan lalat bibit dilakukan dengan insektisida berbahan aktif karbofuran. Pengendalian hama penggerek daun menggunakan insektisida berbahan aktif beta siflutrin. Karakter yang diamati meliputi: hasil biji (ton ha-1), panjang tongkol $(\mathrm{cm})$, diameter tongkol $(\mathrm{cm})$, jumlah baris biji (baris), rendemen (\%) dan bobot 1,000 biji (g).

Analisis data dilakukan dua tahap, yaitu analisis ragam untuk mengetahui perbedaan respon antar genotipe, analisis daya gabung (daya gabung umum/DGU dan daya gabung khusus/DGK) serta efek heterosis. Analisis daya gabung menggunakan model Griffing metode 2 model 1 (Basuki, 2005). Untuk mengetahui perbedaan dari masing- masing pengaruh daya gabung digunakan nilai CD (Critical Difference) yang dihitung dengan rumus:

$$
\begin{aligned}
\mathrm{CD} & =\mathrm{SE} \times \mathrm{t}_{\text {tabel }}(\alpha=5 \%) \\
& =\sqrt{\operatorname{var}} \times \mathrm{t}_{\text {tabel }}
\end{aligned}
$$

Efek heterosis dihitung dengan menentukan nilai heterosis tetua tertinggi (high parent heterosis = heterobeltiosis) (Hallauer dan Miranda, 1988), dengan rumus Heterobeltiosis $=((\mathrm{F} 1-\mathrm{HP}) / \mathrm{HP}) \times 100 \%, \mathrm{~F} 1=$ rerata penampilan hibrida dan $\mathrm{HP}=$ rerata penampilan tetua tertinggi. Analisis daya gabung dan heterosis diolah menggunakan program MS Excel 2007.

\section{HASIL DAN PEMBAHASAN}

\section{Daya Gabung Umum}

Hasil analisis ragam menunjukkan bahwa antara galur dan hibrida yang diuji terdapat perbedaan pada taraf 5\% untuk karakter hasil dan komponen hasil (Tabel 1). Hasil analisis ragam daya gabung menunjukkan pengaruh nyata baik pada DGU maupun DGK pada semua karakter. Ragam DGU dan DGK yang nyata memberikan indikasi bahwa baik gen aditif maupun non-aditif memberikan pengaruh nyata pada karakter yang diamati. Hasil ini sesuai dengan yang ditemukan oleh Abdel-Moneam et al. (2009); Zivanovic et al. (2010); Bocanski et al. (2010) dan El-Badawy (2012) dimana DGU dan DGK berpengaruh nyata pada karakter hasil biji, panjang tongkol, diameter tongkol, jumlah baris biji, rendemen dan bobot 1,000 biji. Penelitian Iriany et al. (2011), DGU dan DGK berpengaruh nyata pada hasil biji dan diameter tongkol. Hal tersebut juga menunjukkan peran aksi gen aditif dan dominan pada karakter hasil dan komponen hasil. Poehlman dan Sleper (1995) menyatakan bahwa karakter dengan DGU nyata dikendalikan oleh aksi gen aditif, sedangkan karakter dengan DGK nyata dikendalikan oleh aksi gen dominan (non aditif).

Hampir semua galur mempunyai nilai DGU positif dan berbeda nyata, kecuali PWM-2 dan PWM-3 (Tabel 2). Nilai positif ini menunjukkan galur tersebut berpengaruh pada pertambahan tinggi pada karakter hasil biji dan panjang atau besar pada komponen hasil. Galur penggabung baik untuk karakter hasil biji yaitu PWM-1, PWM-5, dan PWI-5; untuk panjang tongkol yaitu PWM-1, PWI-2, dan PWI-5; untuk diameter tongkol yaitu PWM-1, PWM-5, dan PWI-1; untuk jumlah baris biji yaitu PWM-1 dan PWM5; untuk rendemen yaitu PWM-1, PWM-4, PWI-3, PWI4, PWI-5; dan untuk bobot 1,000 biji yaitu PWI-1, PWI-2, dan PWI-5. Galur-galur dengan DGU positif diharapkan memberikan kontribusi jika disilangkan dengan galur lain sehingga menghasilkan hibrida dengan potensi hasil yang lebih tinggi. Galur dengan nilai DGU negatif mempunyai kemampuan bergabung lebih rendah dari pada galur yang lain.

Berdasarkan nilai DGU tersebut galur PWM-1 dan PWI-5 merupakan penggabung yang baik. PWM-1 dari grup PT. Agri Makmur Pertiwi menunjukkan nilai DGU positif dan berbeda nyata pada karakter hasil biji, panjang tongkol, 
Tabel 1. Analisis ragam persilangan dialel jagung untuk karakter hasil dan komponen hasil

\begin{tabular}{|c|c|c|c|c|c|c|c|}
\hline \multirow{2}{*}{$\begin{array}{l}\text { Sumber } \\
\text { keragaman }\end{array}$} & \multirow[b]{2}{*}{$\mathrm{Db}$} & \multicolumn{6}{|c|}{ Kuadrat tengah } \\
\hline & & $\begin{array}{c}\text { Hasil } \\
\text { biji }\end{array}$ & $\begin{array}{l}\text { Panjang } \\
\text { tongkol }\end{array}$ & $\begin{array}{c}\text { Diameter } \\
\text { tongkol }\end{array}$ & $\begin{array}{c}\text { Jumlah baris } \\
\text { biji }\end{array}$ & Rendemen & $\begin{array}{c}\text { Bobot } 1,000 \\
\text { biji }\end{array}$ \\
\hline Ulangan & 2 & $24.36^{*}$ & $26.58 *$ & $0.36^{*}$ & $1.38^{*}$ & $4.53 \mathrm{tn}$ & $915.09 *$ \\
\hline Perlakuan & 54 & $11.38 *$ & $10.18 *$ & $0.61 *$ & $4.16^{*}$ & $20.13 *$ & $5,247.57^{*}$ \\
\hline Galat percobaan & 108 & 1.26 & 1.75 & 0.03 & 0.31 & 1.94 & 140.04 \\
\hline DGU & 9 & $3.02 *$ & $6.22 *$ & $0.35 *$ & $5.66^{*}$ & $26.75^{*}$ & $4,845.51 *$ \\
\hline DGK & 45 & $3.95^{*}$ & $2.83 *$ & $0.17 *$ & $0.53 *$ & $2.7^{*}$ & $1,129.93 *$ \\
\hline Galat Daya Gabung & 108 & 0.42 & 0.58 & 0.01 & 0.10 & 0.65 & 46.68 \\
\hline Total & 164 & & & & & & \\
\hline
\end{tabular}

Keterangan: DGU = daya gabung umum; DGK = daya gabung khusus; $*=$ berpengaruh nyata pada taraf uji $5 \%(\mathrm{P}<0.05)$

diameter tongkol, jumlah baris biji, dan rendemen. Oleh karena itu, PWM-1 dapat dijadikan sebagai penggabung yang baik untuk karakter hasil dan komponen hasil. Dari grup introduksi, galur PWI-5 menunjukkan nilai DGU positif dan berbeda nyata pada karakter hasil biji, panjang tongkol, rendemen dan bobot 1,000 biji.

Jumlah galur dari grup introduksi yang mempunyai nilai DGU positif dan berbeda nyata, lebih banyak daripada galur-galur dari grup PT. Agri Makmur Pertiwi. Hal tersebut disebabkan oleh perbedaan latar belakang genetik, yang berasal dari Thailand. Hal ini sejalan dengan percobaan Fan et al. (2008), yang menunjukkan bahwa karakter hasil dan komponen hasil antara galur dari CIMMYT dan lokal. Galur dari CIMMYT mempunyai efek daya gabung umum yang lebih besar daripada galur lokal. Perbedaan latar belakang genetik mempengaruhi efek daya gabung yang ditimbulkan. Hal tersebut juga sejalan dengan percobaan Fan et al. (2008), Yasin et al. (2008), Haddadi et al. (2012) dan El-Shamarka et al. (2015) yang menggunakan galur dari grup yang berbeda, pada salah satu grup mempunyai pengaruh DGU yang tinggi pada karakter hasil dan karakter komponen hasil.

\section{Daya Gabung Khusus}

Seleksi berdasarkan karakter hasil biji dan nilai DGK positif menghasilkan 22 hibrida terpilih. Hibrida yang terpilih mempunyai hasil biji diatas rerata semua hibrida dan terdiri atas 3 hibrida grup PT. Agri Makmur Pertiwi, 7 hibrida grup introduksi dan 12 hibrida kombinasi antara grup introduksi dan PT. Agri Makmur Pertiwi.

Nilai DGK positif dan berbeda nyata ditemui pada hampir semua hibrida. Nilai DGK positif menunjukkan bahwa tetua tersebut mempunyai kombinasi hibrida yang tinggi dengan salah satu tetua yang digunakan. Nilai DGK pada karakter hasil biji dan diameter tongkol menunjukkan nilai positif, hal tersebut sejalan dengan penelitian Abdel-Moneam et al. (2009), Zivanovic et al. (2010) dan Yustiana et al. (2013). Nilai DGK yang tinggi pada hasil biji dan diameter tongkol juga dilaporkan oleh Iriany et al. (2011) pada percobaan jagung manis. Pada grup introduksi mempunyai jumlah hibrida dengan DGK nyata lebih banyak daripada grup PT. Agri Makmur Pertiwi, sedangkan kombinasi kedua grup tersebut mempunyai jumlah hibrida dengan DGK nyata lebih banyak dari pada

Tabel 2. Daya gabung umum (DGU) galur jagung untuk karakter hasil dan komponen hasil

\begin{tabular}{lcccccc}
\hline Galur & Hasil biji & $\begin{array}{c}\text { Panjang } \\
\text { tongkol }\end{array}$ & $\begin{array}{c}\text { Diameter } \\
\text { tongkol }\end{array}$ & $\begin{array}{c}\text { Jumlah baris } \\
\text { biji }\end{array}$ & $\begin{array}{c}\text { Rendemen } \\
\text { Bobot 1,000 } \\
\text { biji }\end{array}$ \\
\hline PWM-1 & $0.58^{*}$ & $0.71^{*}$ & $0.08^{*}$ & $0.62^{*}$ & $1.34^{*}$ & $-8.32^{*}$ \\
PWM-2 & $-0.54^{*}$ & -0.39 & 0.05 & 0.17 & $-2.4^{*}$ & $-20.71^{*}$ \\
PWM-3 & $-0.50^{*}$ & $-0.93^{*}$ & $-0.24^{*}$ & $-0.79^{*}$ & -0.31 & $-15.35^{*}$ \\
PWM-4 & $-0.81^{*}$ & $-0.6^{*}$ & $-0.11^{*}$ & $-0.49^{*}$ & $1.34^{*}$ & -2.04 \\
PWM-5 & $0.76^{*}$ & -0.05 & $0.32^{*}$ & $1.49^{*}$ & 0.14 & -0.27 \\
PWI-1 & -0.05 & $-0.63^{*}$ & $0.21^{*}$ & $-0.31^{*}$ & $-1.47^{*}$ & $50.33^{*}$ \\
PWI-2 & -0.03 & $1.04^{*}$ & 0.01 & 0.15 & $-1.93^{*}$ & $4.45^{*}$ \\
PWI-3 & 0.15 & 0.21 & $-0.09^{*}$ & 0.15 & $0.69^{*}$ & $-14.43^{*}$ \\
PWI-4 & 0.08 & $-0.42^{*}$ & $-0.09^{*}$ & $-0.26^{*}$ & $1.94^{*}$ & $-4.4^{*}$ \\
PWI-5 & $0.35^{*}$ & $1.05^{*}$ & $-0.14^{*}$ & $-0.74^{*}$ & $0.66^{*}$ & $10.74^{*}$ \\
CD 5\% & 0.35 & 0.41 & 0.05 & 0.17 & 0.43 & 3.67 \\
\hline
\end{tabular}

Keterangan: * = berbeda nyata berdasarkan uji Critical Difference pada taraf $5 \%(\mathrm{P}<0.05)$ 
kedua grup penyusunnya. Pada karakter panjang tongkol, diameter tongkol, jumlah baris biji, rendemen serta bobot 1,000 biji mempunyai DGK pada umumnya bernilai positif namun diturunkan juga hibrida yang bernilai negatif (Tabel 3). DGK grup introduksi yang lebih baik, memungkinkan didapatkan hibrida dengan performa baik dari grup ini.

Hibrida PWM-5 x PWM-1, PWI-5 x PWM-1 dan PWI-5 x PWM-5 mempunyai nilai DGK positif tetapi tidak berbeda nyata untuk karakter hasil. Persilangan tersebut tersusun dari galur yang juga mempunyai nilai DGU positif yaitu PWM-1, PWM-5 dan PWI-5. Karakter diameter tongkol, jumlah baris biji dan rendemen juga menunjukkan gejala yang sama, yaitu terdapat hibrida dengan DGK positif dan terbentuk dari 2 galur penyusun dengan DGU positif juga. Namun demikian terdapat juga hibrida dengan nilai DGK positif berasal dari satu galur saja yang mempunyai DGU positif. Penelitian Alam et al. (2008), Abdel-Moneam et al. (2009), Kanagarasu et al. (2010), Haydar dan Paul (2014) dan Niyonzima et al. (2015) menunjukkan bahwa hibrida dengan nilai DGK tinggi biasanya dihasilkan dari persilangan antar kedua tetua mempunyai nilai DGU tinggi, atau paling sedikit salah satu tetuanya mempunyai nilai
DGU tinggi, namun hibrida dengan nilai DGK tinggi dapat juga dihasilkan dari pasangan galur dengan nilai DGU yang rendah.

Penggunaan grup yang berbeda latar belakang genetiknya juga pernah dilaporkan oleh Yasin et al. (2008), Legesse et al. (2009), Zare et al. (2011) dan Yustiana et al. (2013), bahwa galur yang mempunyai DGU baik pada beberapa karakter setidaknya mempunyai satu pasangan persilangan yang menunjukkan DGK yang baik. Suatu galur akan memunculkan suatu sifat baik jika mendapatkan pasangan yang tepat. Galur yang mempunyai DGU tinggi jika dipasangkan dengan galur lain belum tentu menghasilkan hibrida dengan DGK tinggi pula.

\section{Heterosis}

Heterosis berdasarkan tetua tertinggi (heterobeltiosis) pada karakter hasil biji menunjukkan nilai positif, artinya semua hibrida mempunyai hasil biji yang lebih tinggi dari hasil biji tetua tertinggi. Karakter panjang tongkol, diameter tongkol, jumlah baris biji, rendemen dan bobot 1,000 biji menunjukkan nilai heterobeltiosis positif dan negatif (Tabel

Tabel 3. Nilai daya gabung khusus (DGK) 22 kombinasi persilangan terpilih untuk karakter hasil dan komponen hasil jagung

\begin{tabular}{|c|c|c|c|c|c|c|}
\hline Genotipe & Hasil biji & $\begin{array}{l}\text { Panjang } \\
\text { tongkol }\end{array}$ & $\begin{array}{l}\text { Diameter } \\
\text { tongkol }\end{array}$ & $\begin{array}{c}\text { Jumlah baris } \\
\text { biji }\end{array}$ & Rendemen & $\begin{array}{c}\text { Bobot } 1,000 \\
\text { biji }\end{array}$ \\
\hline PWM-2 x PWM-1 & $1.75^{*}$ & $2.12 *$ & $0.18^{*}$ & 0.31 & 0.81 & 4.56 \\
\hline PWM-5 x PWM-1 & 0.60 & 1.01 & $0.19 *$ & $1.05^{*}$ & 0.14 & 3.23 \\
\hline PWM-5 x PWM-3 & 1.15 & -0.34 & 0.16 & 0.19 & -1.29 & $24.12^{*}$ \\
\hline PWI-1 x PWM-1 & 0.74 & -0.74 & $0.29 *$ & 0.25 & 0.84 & $30.49^{*}$ \\
\hline PWI-2 x PWM-1 & 0.33 & 1.08 & $0.27 *$ & $0.79 *$ & 0.90 & $-19.10^{*}$ \\
\hline PWI-3 x PWM-1 & $1.90 *$ & 0.86 & 0.17 & -0.34 & 1.10 & $30.05^{*}$ \\
\hline PWI-5 x PWM-1 & 1.12 & $1.96^{*}$ & $0.27 *$ & $0.74 *$ & 1.03 & 5.42 \\
\hline PWI-4 x PWM-2 & $1.43^{*}$ & $1.38 *$ & $0.22 *$ & -0.01 & 1.44 & -2.16 \\
\hline PWI-5 x PWM-2 & 1.10 & 0.17 & 0.17 & 0.39 & 0.70 & 7.27 \\
\hline PWI-2 x PWM-3 & $1.32 *$ & 1.20 & 0.12 & 0.53 & $1.94 *$ & 10.23 \\
\hline PWI-5 x PWM-3 & $1.39 *$ & 1.05 & -0.02 & 0.02 & $2.86^{*}$ & -0.25 \\
\hline PWI-1 x PWM-4 & $2.25 *$ & -0.05 & $0.47^{*}$ & $1.49 *$ & -0.46 & $23.34^{*}$ \\
\hline PWI-1 x PWM-5 & 0.72 & -1.12 & 0.13 & 0.18 & 0.81 & 5.24 \\
\hline PWI-3 x PWM-5 & 0.64 & 0.54 & -0.13 & -0.22 & -0.06 & 7.67 \\
\hline PWI-5 x PWM-5 & 0.87 & 0.87 & 0.16 & $-0.59 *$ & -0.55 & $17.67 *$ \\
\hline PWI-2 x PWI-1 & $1.80^{*}$ & 0.07 & 0.16 & 0.45 & $1.86^{*}$ & $15.45^{*}$ \\
\hline PWI-3 x PWI-2 & $1.93 *$ & $2.00 *$ & $0.22 *$ & 0.52 & 1.26 & 2.96 \\
\hline PWI-4 x PWI-2 & $2.72 *$ & $2.09 *$ & $0.64 *$ & 0.34 & $-3.39 *$ & $139.30 *$ \\
\hline PWI-5 x PWI-2 & $2.02 *$ & $-1.52^{*}$ & $0.42 *$ & $1.61^{*}$ & 1.16 & $-26.86^{*}$ \\
\hline PWI-4 x PWI-3 & 1.09 & $1.79 *$ & 0.10 & 0.41 & 0.44 & $-14.97 *$ \\
\hline PWI-5 x PWI-3 & $1.39 *$ & 0.64 & 0.16 & -0.12 & 0.21 & 3.76 \\
\hline PWI-5 x PWI-4 & 1.05 & 1.06 & $0.18^{*}$ & 0.43 & 0.63 & 6.06 \\
\hline CD $5 \%$ & 1.17 & 1.38 & 0.18 & 0.58 & 1.45 & 12.34 \\
\hline
\end{tabular}

Keterangan: * = berbeda nyata berdasarkan uji Critical Difference pada taraf 5\% $(\mathrm{P}<0.05)$ 
4). Hasil tersebut juga sejalan dengan penelitian yang dilakukan, Alam et al. (2008), Abdel-Moneam et al. (2009), Iriany et al. (2011) dan Kumar et al. (2014).

Hibrida PWI-5 x PWI-2 mempunyai nilai heterobeltiosis tertinggi untuk karakter hasil biji dan jumlah baris biji. Hibrida PWI-4 x PWI-3 mempunyai nilai heterobeltiosis tertinggi untuk karakter panjang tongkol. Hibrida PWI-4 x PWI-2 mempunyai nilai heterobeltiosis tertinggi untuk karakter diameter tongkol dan bobot 1,000 biji, sedangkan hibrida PWI-2 x PWI-1 mempunyai nilai heterobeltiosis tertinggi untuk karakter rendemen. Berdasarkan hasil tersebut kedua grup jagung menunjukkan efek heterosis yang berbeda. Efek heterosis grup PT. Agri Makmur Pertiwi memiliki nilai rerata dibawah grup introduksi. Nilai rerata heterobeltiosis untuk karakter hasil biji yang dimiliki grup PT. Agri Makmur Pertiwi sebesar $51.87 \%$ (34.91-77.71\%), lebih rendah daripada grup introduksi yang mencapai 130.44\% (109.61-169.24\%), sedangkan kombinasi kedua grup introduksi dan PT. Agri Makmur Pertiwi sebesar 86.02\% (35.36-156.46\%) berada diantara keduanya. Perbedaan respon heterosis pada hibrida sangat dipengaruhi oleh latar belakang genetik dari tetuanya atau populasi awal pembentuk tetua (Abuali et al., 2012). Hibrida terpilih yang mempunyai DGK tertinggi, biasanya juga mempunyai heterobeltiosis tertinggi, seperti pada karakter diameter tongkol, jumlah baris biji, bobot 1,000 biji, seperti dilaporkan oleh El-Shamarka et al. (2015) yang menggunakan 8 galur dengan keragaman yang luas, terdapat 2 hibrida yang mempunyai DGK tinggi dan juga heterosis yang tinggi pula.

Tabel 4. Heterobeltiosis kombinasi persilangan terpilih untuk karakter hasil dan komponen hasil jagung

\begin{tabular}{|c|c|c|c|c|c|c|}
\hline Genotipe & $\begin{array}{c}\text { Hasil } \\
\text { biji }\end{array}$ & $\begin{array}{l}\text { Panjang } \\
\text { tongkol }\end{array}$ & $\begin{array}{c}\text { Diameter } \\
\text { tongkol }\end{array}$ & $\begin{array}{c}\text { Jumlah baris } \\
\text { biji }\end{array}$ & Rendemen & $\begin{array}{c}\text { Bobot } 1,000 \\
\text { biji }\end{array}$ \\
\hline PWM-2 x PWM-1 & $77.71 * *$ & $28.27 * *$ & $23.53 * *$ & $10.84 * *$ & -3.65 & 7.31 \\
\hline PWM-5 x PWM-1 & $42.99 * *$ & $19.60 * *$ & $4.99 * *$ & 0.39 & -1.33 & 2.50 \\
\hline PWM-5 x PWM-3 & $34.91 * *$ & -2.71 & -1.80 & -12.94 & -3.87 & 7.08 \\
\hline PWI-1 x PWM-1 & $67.77 * *$ & $4.55^{* *}$ & $30.31 * *$ & $6.90 * *$ & -2.46 & 8.70 \\
\hline PWI-2 x PWM-1 & $60.33 * *$ & $23.02 * *$ & $24.86 * *$ & $14.29 * *$ & -2.96 & 7.20 \\
\hline PWI-3 x PWM-1 & $93.53 * *$ & $23.23 * *$ & $19.90 * *$ & $5.91 * *$ & 0.52 & 19.01 \\
\hline PWI-5 x PWM-1 & $82.63 * *$ & $37.77 * *$ & $20.97 * *$ & $7.39 * *$ & 0.39 & 4.96 \\
\hline PWI-4 x PWM-2 & $97.93^{* *}$ & $24.60 * *$ & $20.31 * *$ & $2.48 * *$ & -6.41 & 7.63 \\
\hline PWI-5 x PWM-2 & $156.46^{* *}$ & $15.80 * *$ & $17.67 * *$ & $1.98 * *$ & 2.00 & 1.55 \\
\hline PWI-2 x PWM-3 & $121.58 * *$ & $12.12 * *$ & $17.47 * *$ & $10.11 * *$ & -2.44 & 15.37 \\
\hline PWI-5 x PWM-3 & $133.61 * *$ & $18.31 * *$ & $18.03 * *$ & $1.09^{*}$ & 1.94 & 0.84 \\
\hline PWI-1 x PWM-4 & $102.29 * *$ & $12.82 * *$ & $32.40 * *$ & $15.87 * *$ & -5.04 & 8.46 \\
\hline PWI-1 x PWM-5 & $35.36^{* *}$ & -6.24 & $6.59 * *$ & -10.20 & -0.45 & 3.88 \\
\hline PWI-3 x PWM-5 & $37.09 * *$ & $12.40 * *$ & -4.52 & -9.85 & 0.95 & 1.95 \\
\hline PWI-5 x PWM-5 & $43.70 * *$ & $21.06 * *$ & 0.13 & -17.25 & 0.53 & 11.55 \\
\hline PWI-2 x PWI-1 & $109.61 * *$ & $6.23 * *$ & $27.70 * *$ & $13.30 * *$ & $4.23 * *$ & 8.06 \\
\hline PWI-3 x PWI-2 & $141.54 * *$ & $26.07 * *$ & $24.14^{* *}$ & $11.62 * *$ & 0.00 & 13.04 \\
\hline PWI-4 x PWI-2 & $139.56^{* *}$ & $22.21 * *$ & $34.70 * *$ & $7.07 * *$ & -11.55 & $66.64 * *$ \\
\hline PWI-5 x PWI-2 & $169.24 * *$ & $6.85 * *$ & $27.74 * *$ & $19.15^{* *}$ & $3.23 *$ & -1.36 \\
\hline PWI-4 x PWI-3 & $105.72 * *$ & $45.22 * *$ & $18.85^{* *}$ & $7.58 * *$ & -3.96 & 5.19 \\
\hline PWI-5 x PWI-3 & $137.69 * *$ & $23.90 * *$ & $20.49 * *$ & 0.00 & 1.95 & 2.44 \\
\hline PWI-5 x PWI-4 & $109.72 * *$ & $22.35^{* *}$ & $19.54 * *$ & 1.01 & -3.77 & 6.44 \\
\hline t Test $5 \%$ & 2.08 & 2.46 & 0.32 & 1.03 & 2.59 & 21.96 \\
\hline t Test $1 \%$ & 2.63 & 3.10 & 0.41 & 1.30 & 3.26 & 27.69 \\
\hline
\end{tabular}

Keterangan: $* *=$ berpengaruh nyata berdasarkan uji t pada taraf uji $1 \%(\mathrm{P}<0.01) ; *$ berpengaruh nyata pada taraf uji $5 \%(\mathrm{P}<0.05)$

\section{KESIMPULAN}

Galur PWM-1 (grup PT. Agri Makmur Pertiwi) dan PWI-5 (grup introduksi) mempunyai DGU yang lebih baik dibandingkan dengan galur lain pada karakter hasil biji, panjang tongkol, diameter tongkol, jumlah baris biji, rendemen dan bobot 1,000 biji dan dapat diarahkan untuk perakitan jagung bersari bebas. Hibrida PWM-5 x PWM-1, PWI-5 x PWM-1 dan PWI-5 x PWM-5 mempunyai nilai DGK positif dan galur pembentuknya juga mempunyai nilai 
DGU positif, sehingga dapat digunakan sebagai hibrida baru. Persilangan didalam grup introduksi mempunyai heterosis tertinggi untuk semua karakter. Hibrida yang mempunyai DGK dan heterobeltiosis tertinggi yaitu PWI-4 x PWI-2 (karakter diameter tongkol dan bobot 1,000 biji) dan PWI-5 x PWI-2 (karakter jumlah baris biji).

\section{DAFTAR PUSTAKA}

Abdel-Moneam, M.A., A.N. Attia, M.I. El-Amery, E.A. Fayed. 2009. Combining ability and heterosis for some agronomic traits in crosses of maize. Pak. J. Biol. Sci. 12:433-438.

Abuali, A.I., A.A. Abdelmulla, M.M. Khalafalla, A.E. Idris, A.M. Osman. 2012. Combining ability and heterosis for yield and yield component in maize (Zea mays L.). Aust. J. Basic Appl. Sci. 6:36-41.

Alam, A.K.M.M., S. Ahmed, M. Begum, M.K. Sultan. 2008. Heterosis and combining ability for grain yield and its contributing characters in maize. Banglades J. Agr. Res. 33:375-379.

Basuki, N. 2005. Genetika Kuantitatif. Fakultas Pertanian, Unibraw, Malang.

Bocanski, J., Z. Sreckov, A. Nastasic, M. Ivanovic, I. Djalovic, M. Vukosavijev. 2010. Mode of inheritance and combining abilities for kernel row number, kernel number per row and grain yield in maize (Zea mays L.). Genet 42:167-176.

El-Badawy, M.M. 2012. Heterosis and combining ability in maize using diallel crosses among seven new inbred lines. Asian J. Crop Sci. 5:1-13.

El-Shamarka, S.A., M.A.S. Ahmed, M.M. El-Nahas. 2015. Heterosis and combining ability for yield and its components through diallel cross analysis in maize (Zea mays L.). Alex. J. Agric. Res. 60:87-94.

Fan, X.M., H.M. Chen, J. Tan, C.X. Xu, Y.D. Zhang, L.M. Luo, Y.X. Huang, M.S. Kang. 2008. Combining abilities for yield and yield components in maize. Maydica 53:39-46.

Haddadi, M.H., M. Eesmaeilof, R. Choukan, V. Rameeh. 2012. Combining ability analysis of days to silking, plant height, yield components and kernel yield in maize breeding lines. Afr. J. Agric. Res. 7:46854691 .

Hallauer, A.R., J.B. Miranda. 1988. Quantitative Genetics in Maize Breeding. Second Edition. Iowa State University Press, America.

Haydar, F.M.A., N.K. Paul. 2014. Combining ability analysis for different yield components in maize (Zea mays
L.) inbred lines. Bangladesh J. Plant Breed. Genet. 27:17-23.

Iriany, R.N., S. Sujiprihati, M. Syukur, J. Koswara, M. Yunus. 2011. Evaluasi daya gabung dan heterosis lima galur jagung manis (Zea mays var. saccharata) hasil persilangan dialel. J. Agron. Indonesia 39:103111.

Kanagarasu, S., G. Nallathambi, K.N. Ganesan. 2010. Combining ability analysis for yield and its component traits in maize (Zea mays L.). Electronic J. Plant Breeding 1:915-920.

Kumar, G.P., Y. Prashanth, V.N. Reddy, S.S. Kumar, P.V. Rao. 2014. Heterosis for grain yield and its component traits in maize (Zea mays L.). Int. J. Pure App. Biosci. 2:106-111.

Legesse, B.W., K.V. Pixley, A.M. Botha. 2009. Combining ability and heterotic grouping of highland transition maize inbred lines. Maydica 54:1-9.

Niyonzima, J.P., T.E. Nagaraja, H.C. Lohithaswa, M.S. Uma, R. Pavan, F. Niyitanga, A. Kabayiza. 2015. Combining ability study for grain yield and its contributing characters in maize (Zea mays L.). Int. J. Agron. Agric. Res. 7:61-69.

Poehlman, J.M., D.A. Sleper. 1995. Breeding Field Crops. Fourth Edition. Iowa State University Press, America.

Sprague, G.F., L.A. Tatum. 1942. General vs specific combining ability in single crosses of corn. J. Amer. Soc. Agron. 34:923-932.

Takdir, A., R.N. Iriany, M. Isnaini, A. Muliadi. 2007. Combining ability of CIMMYT maize lines with two Indonesian tester parents. J. Penelitian Pertanian 26:161-166.

Yasin, M., A. Rahman, N.A. Subekti. 2008. Daya gabung umum dan daya gabung spesifik lima galur harapan jagung berprotein mutu tinggi. J. Penelitian Pertanian 27:76-80.

Yustiana, M. Syukur, S.H. Sutjahjo. 2013. Analisis daya gabung galur-galur jagung tropis di dua lokasi. J. Agron. Indonesia 41:105-111.

Zare, M., R. Choukan, E.M. Heravan, M.R. Bihamta, K. Ordookhani. 2011. Gene action of some agronomic traits in corn (Zea mays L.) using diallel cross analysis. Afr. J. Agric. Res. 6:693-703.

Zivanovic, T., G. Brankovic, S. Radanovic. 2010. Combining abilities of maize inbred for grain yield and yield component. Genet. 42:565-574. 